\title{
The Utility Extent of Linguistics to Language Teaching: An Experimental Evaluation
}

\author{
Md. Faruquzzaman Akan \\ Hassan Mahill Abdallah Hassan \\ A B M Shafiqul Islam \\ Abdelrahman Elyass Mohamed Abdelmajd \\ Faculty of Languages and Translation, King Khalid University, Abha, KSA \\ e-mail:f.akan@yahoo.com
}

\begin{abstract}
To approach the very questions 'how' and 'how far' linguistics helps language teaching, we have to examine, analyze and evaluate them critically from various view-points. It is well-noted that inguistics and language teaching have the same subject matter to deal with. Though linguistics is the scientific study of language, it has some specific role to play in the process of language teaching from the earlier to the modern times. Stephen Pit Corder (1975:143) says, “... the relevance of theoretical linguistics to language teaching is indirect and it is not the task of a theoretical linguist to say what relevance it may have. This is the field of applied linguistics." According to the American linguist Noam Chomsky and some others, applied linguistics has a direct relationship with language teaching which is a pragmatic process and cannot take place in a total isolation. It takes help from various related sources and fields such as general, educational and social psychology; sociology, social anthropology and so on. Here, linguistics provides a language teacher with effective tools. However, as Dwight Bollinger says (1975a:22), "Language teaching is not linguistics, any more than medicine is chemistry...." The importance of linguistics in language teaching was noticed forthwith for the first time during the Second World War. So, the aim of this paper is to show the role of linguistics in teaching both foreign languages and any first languages or mother tongues.

Keywords: Linguistics, Language Teaching, Puberty, Foreign Language, Native Language
\end{abstract}




\section{INTRODUCTION}

In recent trends, the role and relation of linguistics to language teaching is a recurrent pedagogical and academic concern all over the world. These two disciplines - linguistics and language teaching - have a huge correlation because 'language' is their core area of interest. 'Linguistics' is usually defined as the scientific study of language which has the same subject matter as of language teaching. On the other hand, by 'language teaching' we mean a collective term used to denote all educational theory and practice concerned with the instruction in both the native and foreign language. In fact, linguistics can help language teaching in many ways though it is a different field of study. But the relationship between linguistics and language teaching is not always a crystal clear rather a controversial issue. Many linguists have argued that linguistics has nothing to say to the language teacher. Sampson (1980:10) mentions, "I do not believe that linguistics has any contribution to make to the teaching ..." But Johnson (1982:10) points out, "Language teachers have always looked to the linguist for guidance on how to teach languages". Language after all, is what both the language teacher and the linguist are concerned with: the teacher is concerned with "teaching something which is the object of study of linguistics, and is described by linguistic methods" (M.A.K. Halliday, Angus McIntosh and Peter Strevens 1964:166). Stephen Pit Corder (1975) says, linguistic theories are made to do two things, i.e. to explain language and to make descriptions of languages. So, llinguistics will, therefore, always be a field of study relevant to language teaching. But the problem, of course, is to determine the precise nature of this 'relevance'.

\section{DISCUSSION}

Linguistics and language teaching are often considered to be two very relevant fields of study for they have the same subject matter to handle. Linguistics as the study of language, a human phenomenon, is now an autonomous and well developed discipline of social science. D. A. Wilkins states (1972:215), "Linguistics as the study of all languages as well as the development of language as a human phenomenon is now a complete and autonomous discipline." It got its starting of the journey in the 1960's and in recent times it is widely known and taught all over the world. It is now an independent and full-fledged discipline and its domain is the discussion on any language and everything about or relating to language. Linguistics arose as a discipline largely out of the work of an American linguist, Professor Noam Chomsky and his associates. The aim of linguistics is to develop theories to explain language behaviours, to make the most accurate and comprehensive description of language. In the early $20^{\text {th }}$ century, the founder of modern linguistics, the greatest Swiss scholar, Ferdinand de Saussure introduced a major distinction of linguistics as diachronic, the study of language change and synchronic, the study of the state of language at any given point of time. But now, there are other branches of theoretical linguistics such as phonetics, phonology, grammar (morphology and syntax), structural linguistics, semantics, pragmatics, transformational generative linguistics, discourse analysis etc and applied linguistics has also divisions or branches: psycholinguistics, sociolinguistics, contrastive linguistics/analysis, 
stylistics, information theory etc all of which are any how connected to language teaching. Robert Lado (1964:18) says, "Linguistics is such a science that describes and categorizes languages".

We all know language is characteristically complex. So, what linguistics has to do is to recognize the fundamentals or aspects in order to analyze it. For instance, to talk about a language we try to analyze it from four aspects such as sound system, grammatical system, lexical system and discourse system. But the aspect of exclusion or inclusion of our language teaching practice or teaching theory may be asked. Theoretically speaking, all these four aspects should be involved in our teaching theory, because they make up a whole picture of language. When we analyze each aspect, we will use linguistic theory to describe it, which means we have to consider how it works linguistically; what does it mean semantically and how is it used sociolinguistically. Nonetheless, language teachers wish to teach language as a whole, that means language should be regarded as a synthesis in our teaching practice. As a result, a satisfactory language teaching theory should consider the language both as isolated features and as a synthesis. Language teaching may also refer to learning about language and to understand by four basic skills of language: listening, speaking, reading, writing or any part of it. Here, we can find the role of phonetics, phonology, morphology, syntax and semantics which all belong to linguistics. M.A.K. Halliday, Angus McIntosh and Peter Strevens say (1965:257),

"In our view the primary task of Language teaching is to impart practical command of the four basic skills of Language for use in the widest possible range of difficult situations."

Traditionally, language teaching was conducted with The Grammar Translation Method and various literary reading. But this method was specially used for the teaching of classical languages. In 1957, Noam Chomsky introduced transformational generative linguistics. He said that language learning is not behaviouristic but cognitive and in-built skills work a lot in this matter. After 1880 's, psychology came to function in language teaching at first and behavioristic psychology got the form of direct method in language teaching. In the last half of $20^{\text {th }}$ century, we have got a good number of methods for language teaching such as Audio-lingual Method, The Silent Way, Total Physical Response, The Natural Way, Communicative Language Teaching, Suggestopedia, Community Language Learning etc. Nowadays, the knowledge of linguists is being used in language teaching so far as possible.

\section{LITERATURE REVIEW}

Although 'language' is the very substance of both linguistics and language teaching, many linguists by and large are not very clear about 'how' and 'how far' linguistics helps language teaching. Linguists like Noam Chomsky and many others came to the conclusion that linguistics can help language teaching. In accordance with their opinion, applied linguistics has direct relationship to language teaching but general, pure or theoretical linguistics does not help language teaching directly; 
it can help indirectly. Stephen Pit Corder says (1975:143), “... the relevance of theoretical linguistics to language teaching is indirect and it is not the task of theoretical linguist to say what relevance it may have. This is the field of applied linguistics." To determine the importance of linguistics in language teaching, we must express our agreement with Swales' answer to the following question: Are there hopes for a more interdisciplinary relationship between linguistics and language teaching? Not until Chomsky stops asserting that all questions concerning that relationship are 'trivial' and 'uninteresting' (1993:291). The importance and relevance of linguistics to language teaching first came to notice directly during the World War-II. Then the Audio-lingual Method was followed to teach a language in a very short time so that one could have a working knowledge of language. However, it is often difficult to apply linguistics to language teaching as linguistics has different aims and objectives from language teaching. Here, we can remember Dwight Bolinger's (1975a:22) comment,

"Language teaching is not linguistics, any more than medicine is chemistry ... it makes no difference, and it should make no difference, to the language teacher whether what he takes from linguistics is based on one theory or another or no theory at all, provided it helps him to achieve the goals he is aiming at."

The branches of linguistics are concerned with how languages are structured, how languages are used, and how they change etc. We have known from the linguists' opinion that pure linguistics does not help language teaching directly and applied linguistics has direct influence on language teaching. So, language teaching is the practical activity of applied linguistics.

\section{FUNCTIONS OF LINGUISTICS}

We could look at the functions of linguistics in language teaching from the point of four fundamental questions such as what, when, why and how a language should be learnt and which is supposed to stand in the first place. As we have known from the linguists' opinion that pure linguistics does not help language teaching directly, the answers can be extracted from applied linguistics which tries to solve the problems of what is to be learnt, when is to be learnt, how is to be learnt, and why is to be learnt.

Language teaching and learning is a systematic process. It makes proper selection of learning items. So, the explicit indications for ' what should be learnt' come from linguistic investigation and description. In this connection D. A. Wilkins says (1972:216),

"It is hard to imagine the language can ever be taught without reference to the available language descriptions. In that case, linguistics will always be a field of study relevant to language teaching."

A language teacher can be benefited from linguistics about the question of what and when things should be read. The answer of when and how language is to be 
learnt is available in psycholinguistics and sociolinguistics respectively. Psychologists and sociolinguists are aware of language and their discussion on language which is valuable for the other. Sociolinguistics deals with realistic rather than abstract language situation. Then a major aim of the language teacher should be to reduce the non-native behaviour of his/her learners. The individual differences have also many impacts on language teaching. The way how a child picks up his language is tried by psycholinguists and after that a teacher takes help from psychological theories of teaching such as Behaviourism, Mentalist theory etc. So, the answer of how can also come from social, economical and political needs of the learner which are the task of sociolinguists as the theory, method and technique for learning a language are developed in applied linguistics. Roger W. Shuy (1973:I3) argues,

"The child is surrounded by people who speak with variation based on social status, sex, age and style. He is faced with conflicting pressures to conform the norms of his peers, his parents, his school and his region ...."

Let us look at the function of two broad classes of linguistics: theoretical (pure or general) linguistics and applied linguistics in language teaching. This relationship can be shown in the diagram below:

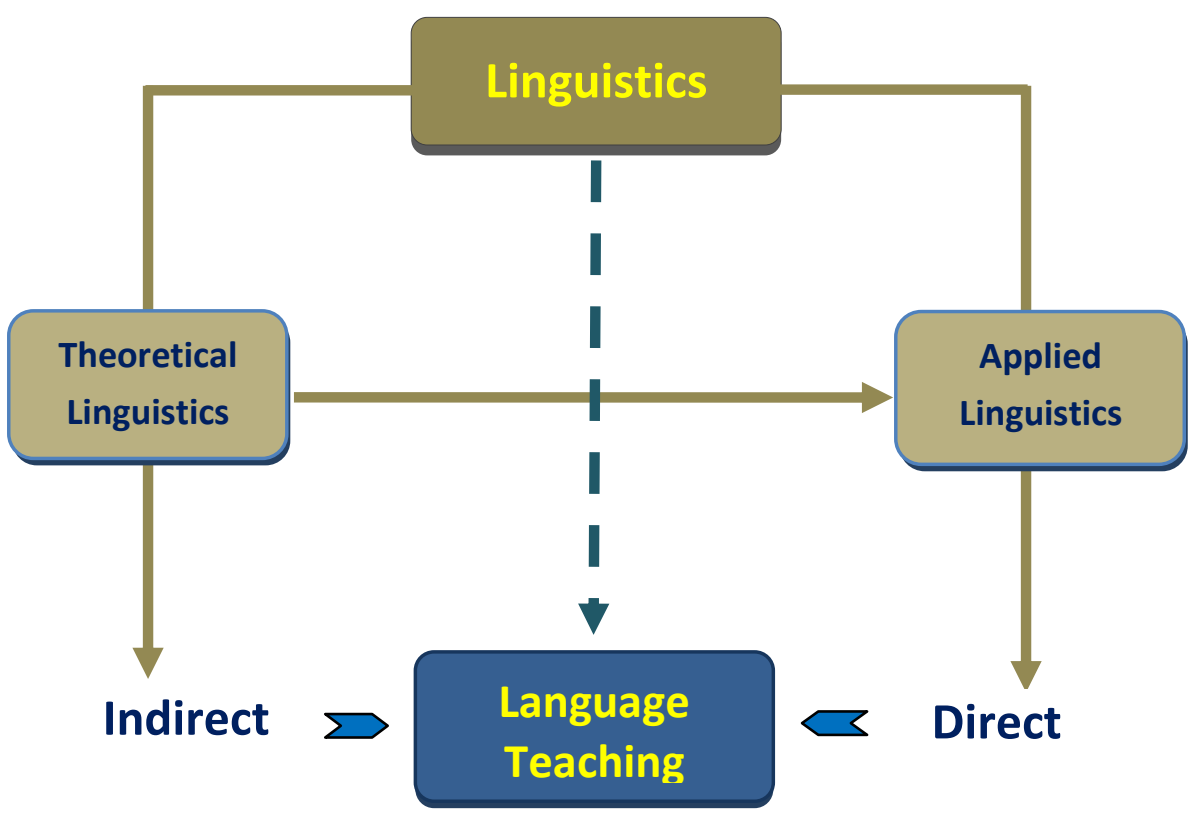

When the knowledge of theoretical linguistics is used for language teaching, it obviously comes under the domain or area of applied linguistics. Though many terms used by linguists appear to be out of the control of a language teacher, we cannot deny that linguistics helps a teacher to be more competent. We also cannot deny the necessity and argument of linguistics when we have to learn two of the four basic skills (i.e. reading and writing) even in one's mother tongue as well as in a foreign language. 


\section{The role of linguistics in language teaching as D. A. Wilkins mentions (1972) can be described in terms of the following four aspects}

To begin with, D. A. Wilkins talks about insights which are the linguistic notions that increase one's understanding of the nature of language and consequently of the nature of language learning. But they do this without necessarily providing specific points of information. Language teaching decisions have to be taken at many different levels- defining the goals of learning, determining the broad methodological approaches, assessing the value of particular techniques, organizing the language content and there can be a few more. In this respect, a number of ways in which linguistics can help the language teacher than any other thing to make much informed decisions. Linguistics defines the relationship between speech and writing. A teacher cannot ignore speech though his objective is writing. In defining his/her aims and developing methodology, the teacher will find it informative to look at the linguists' discussion of the langue/parole distinction. The notion of structure with reference to grammar, idea of phonology and semantics can enrich one's understanding of language. For example, the surface structure of sentences may be the same but the deep structure is different. If language teaching materials are organized on grammatical lines, an awareness of possible differences and similarities in deep structure can be valuable. The distinction between form and meaning is also useful in the analysis of learning. Sometimes, the insights provided by the linguists are not really novel and helpful since there are times when important notions remain unexpressed or overlooked. Our language competence consists of the ability to recognize and construct grammatically correct sentences. So, the uttering of remembered phrases and sentences is not the true language behaviour. One suspects that the greater the technicality of the issue, the less likely its relevance to language teaching. Oller, J. W. (1970:507) claims that pragmatics has implications for language teaching; it defines the goal of teaching a language as prompting the students not merely to manipulate meaningless sound sequences, but to send and receive messages in the language. For instance, in daily conversation, people often speak in an indirect way, maybe we have noticed it, but without the knowledge of pragmatics, we cannot give a correct explanation for it.

In the second place, the term implications denote some significant hints that help the language teacher to make scores of decisions about the methods and techniques s/he uses everyday in the classroom. All these decisions improve the process of learning whether or not one is aware of it. In grammatical matters, when a new word occurs, the teacher has a multitude of options to explain that item. S/he may explain the meaning of the item by translation or aided by the meditation of the first language or with one or more visual images or exemplify in numerous sentences. S/he may repeat the item for the learners. So, the teacher should be careful of his/her method and its implication. Relations of implication exist most obviously between language teaching and what is known as the psychology of language acquisition; the theories of psychology of language learning have implicational relation with language teaching. It is found that translation is a bad thing for the teaching of meaning, but not always neglected. Language teaching aims to be practically effective, not theoretically consistent. The study of linguistics and 
specially the theories of language acquisition help to articulate the implications of many current and proposed practices in language teaching.

To be the penultimate point, D. A. Wilkins refers applications to the cases where notion and information drawn from linguistics act directly upon the process of language teaching. This is the relation that is implied in the term applied linguistics'. Applied linguistics describes how the knowledge of linguistics can be employed in language teaching. Different theories, methods and techniques are discussed extensively by the linguists in applied linguistics. Most language teachers who study linguistics expect to derive application from it. Language description provides the input to the construction of teaching materials. A teacher expects that linguistics will offer him/her a quite new and very different description for his teaching. Linguistics has had less influence on the content of language teaching than linguists have on the methods of teaching. Traditional grammarians restricted their study almost exclusively to written language. Inevitably, the linguists' concern with speech brings new language data within their fields. It is commonly said that two languages can have the same phonetics but different phonology. So, it can be mentioned that there is no pronunciation of double consonants (e.g. Happy /hæpi/) and the post-vocalic ' $r$ ' is not pronounced in (British) English (e.g. Dollar /dplor/). A linguist's description will contain extensive information on the phonetics and phonology of the language concerned. Speech also differs from writing in its grammar and a linguistic description of it will reflect the grammar of speech; not the grammar of writing. This will be new information to the traditionally trained teachers. The attempt to study language in its social relations is a fairly new development and promises to extend our descriptive knowledge. Language descriptions are used in the study of error in language learning. By applying linguistics, we can achieve little that is new.

Finally, the linguistic investigations that have no applications or implications and do not provide insights of significance for teaching of language are represented here as non-applications by D. A. Wilkins (1972). The organization of teaching does not reflect the organization of the language description. In the opinion of Stephen Pit Corder (1975), " ... the theory of language, in fact, has an indirect relation to what is taught in the classroom." A great deal of what occupies a linguist's time will be of little or no value to the language teacher. Language teaching can make use of the product of the rules, but not of the rules themselves. For example, generative phonology which uses abstract terms cannot entire directly into language teaching. For those rules have no direct realization in utterance of the language. Morphological analysis is also of no importance in language teaching. It matters in teaching only that fall contrasts with fell, not whether the past form is analyzed as $/ \mathrm{fpl} /+$-ed, where -ed is realized as $\varnothing$ (zero) or other ways. In recent Transformational Generative description of English, the verbal form of 'he has taken', therefore, consists of: present tense + have + -en + take

Nevertheless, in any actual sentences of the language, of course, the sequence of elements is: (reordered) have $+-s+$ take + -en. These sequences of morphemes are irrelevant to us. Descriptive sequence is not the same thing as pedagogic sequence since the aims of language teaching and linguistics are different. 
To understand sentences having difference in the deep and surface structure, linguistic explanation is helpful. e.g. It is possible. vs. It is not impossible. These two sentences have the same deep structure, but different surface structure. Sometimes, form and meaning may cause serious problem unless correct information is given.

\section{CONCLUSION}

Linguistics is important for language teaching because linguistics and language teaching can be likened to the relationship of knowledge about an engine and the skill in driving a car. It will be better for the driver to be supported with some knowledge about the car or the engine so that he can drive it well and know how to overcome some engine trouble in case s/he has to face it. We do not make developments in linguistics for applying them to language teaching. Instead, when we face problems in language teaching, we look at the evidence from linguistics for the solution. It should be absurd to pretend that no one can be a good language teacher unless s/he has enough knowledge of linguistics. Sometimes, a teacher may use the method given by the linguists unknowingly. But Sumner Ives (1973:397) admits and states with emphasis that linguistics provides a teacher with a very effective tool. So, what s/he does is his/her well-understanding. Teachers' own capability is more important than linguistic methods. Widdowson, H. G. (1978:I3) defined a set of contrasting concepts which distinguish language as a formal system and language use as communicative events. He advocated shifting the emphasis from teaching a second language as a formal system to teaching a second language as communication. His point of view is in accordance with our second language teaching situation. Recently we stressed the importance of students' communicative abilities (that are saying, listening and talking etc.) instead of their linguistic skills. This does not mean we need not the knowledge of linguistics; on the contrary, we use the linguistic theory as a guide for our language teaching. Hutabarat (2016) claims that understanding the underlying theories of second and foreign language acquisition and learning will help both teachers and students in learning and teaching a target language.

The real contribution of linguistics in language teaching is to increase awareness and skills of the teacher. The best modern technique to teach language should be to select the goodness of every method and not to catch hold of a particular method. Noam Chomsky (1966:43) says, "I am frankly, rather skeptical about the significance, for the teaching of languages, of such insights and understanding as have been attained in linguistics and psychology. ... it is difficult to believe that either linguistics or psychology has achieved a level of theoretical understanding that might enable it to support a technology of language teaching."

However, it is found in practice that linguistics plays a good number of roles in language teaching either directly or indirectly. The value of linguistics is that by increasing his/her awareness of language, it makes him/her more competent and thus a better language teacher. But it should be kept in mind that methods are generally less important than the teacher's own competence. So, the relationship between linguistics and language teaching has to be shifted along a continuum from a direct relationship to a more indirect one. 


\section{REFERENCES}

Amin, S. (1981) Bhashatatto O Bhasha Shiksha, Dhaka University Journal, Dhaka (Vol. June, P: 121-134)

Bolinger, D. (1975a) Aspects of Language, $2^{\text {nd }}$ Edition, New York, Harcourt Brace Jovanovich

Brumfit, C. J. \& Roberts, J. T. (1983) A Short Introduction to Language and Language Teaching, Batsford Academic and Educational Ltd. London

Bell, R. T. (1976) Sociolinguistics, St. Martin's Press, New York

Corder, S. P. (1975). Introducing Applied Linguistics, Penguin Book Ltd, Middlesex, England

Chomsky, N. (1965) Aspect of the Theory of Syntax, Cambridge, Mass: MIT Press, England

Crystal, D. (1980) A First Dictionary of Linguistics and Phonetics; Andre Deutsch Ltd, London

De Cecco, J. P. (1967) The Psychology of Language: Thought and Induction, San Francisco

Hartmann, R. R. K. (1972) Dictionary of Language and Linguistics; Stork, F. C. Allied Science Publishers Ltd, UK

Halliday, M. A. K., Mclntosh, A. \& Strevens, P. (1965) The Linguistic Science and Language Teaching; London

Harrol B. Allen \& Lyons, J. (1971) Introduction to Theoretical Linguistics, CUP

Hutabarat, Pritz. (2016). The Relationship between Second Language Acquisition Process and English Language Teaching in Indonesia. JELTL: Journal of English Language Teaching and Linguistics, 1(2), 2016. DOI: http://dx.doi.org/10.21462/jeltl.v1i2.25

Ives, S. (1973) Linguistics in the Classroom Reading Applied Linguistics ed

Lado, R. (1964) Language Teaching: A Scientific Approach; New York, Mcgraw Hill

McAurther, T. (1992) The Oxford Companion to the English Language; OUP, USA

Oller, J. W. (1970). Transformational theory and pragmatics. Modern Language Journal, 54:504-507.

Richards, J. C. \& Rodgers, T. S. (1986) Approaches and Methods in Language Teaching, CUP

Stern, H. H. (1983) Fundamental Concepts in Language Teaching, OUP

Wilkins, D. A. (1972). Linguistics in Language Teaching, Edward Arnold, CUP

Wilkins, D. A. (1972) Linguistics in language teaching. London: Edward Arnold

Widdowson, H. G. (1978). Teaching Language as Communication. Oxford: Oxford University Press 